restored." All this murt be done slowly and gently to avoik cuusing a fracture at the surgieal neck. "The Kocher mothod is based on the exnct knowledge of the pathologic conditions, and is the most perfeet one for this reatson."

The tuaction method is employed when it is impossible to reduce the dislocation by the above moans. There are several ways of applying this, a simple one being to grasp the arm above the elbow and make a stealy traction downward and outward, then gradually abluct the arm until it is nearly at right angles with.the body. Pressure is then miade over the head in the axilla.

Another method is that of Stimson, in which weights are attached to the elbow or wrist (the arm hanging free of the floor as the patient lies upon a table). Ten pounds are added at times one or two minutes apart until to pounds lave been reached, and in from five to fifteen minutes the head is advanced towarl the glenoid cavity by adducting the arm against the fist that has been placed in the axilla.

In fractured dislocations an anesthetic slould be administered and "every method should be tried in order to reduce the head before performing operation." Where other efforts fail McBurney's operation is advised, in which an incision is macle in the soft parts on the onter aspect of the upper fragment, extending down to the bone, and a hole is drilled in the latter, through which a stout hook is inserted and direct traction made on the upper fragment in the proper direction.

Dr. Robert Jones reports twenty-two cases of fracture of the head of the hmmerus associated with dislocation of the shoulder, and after advising the reduction of the dislocation as soon as possible by one of the accepted methods, he adds: "Having reduced the dislocation, the fracture of the humerus is of comparatively little mo. ment and need not be dwelt on." Perfect apposition is not necessary to good results, and he strongly advises against the wiring of fragments in fracture through the surgical neck, his experience with many hundreds of cases of this fracture showing that wiring would not have been of service in a single instance. In order to prevent stiffness of movement after the parts have united, massage and passive movements should be regularly practiced between the fourth and eighth weeks.

For fracture of the clavicle and scapula with displacement the dislocation should be reduced and for the latter cases the arm need only be kept at rest and protected from accidental injuries by the use of a shonlder cap, the use of the axillary pad also being considered useless and even dangerous by some surgica? authorities. When the clavicle is fractured Sayre's method of strapping the arm is advised.

CASE 1.-History.-The patient came into my office Scpt. 30, 1009, saying that on July 18 he had fallen out of a wagon and struck on lis right shoulder. Ile could not move his al'm; pain was severe, but he rot up and went to a plysician, who said that he had a dislocation. Tljis physician tried to rednee it without an anestlontic, but could not, so sent him to another physician in an uljoining tows, who, on July 20, gave the patient an ansethetie. When he woke up he was told that his arm had besesthetic. When hould keep it in

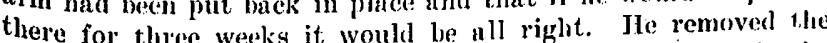
bandage at the end of the three weeks and found his arm in the same position if: was before. JTis a 'm had been paining him ever since and he could not use it only to a limited extent.

Examinations, Tratment and Result.--The fi)'st examination showed shortening of the humeris, very small amount of addine tion and abeluction, anterior and posterior motions being lim. ited, and on exam, antion with the $x$-ray made a probable disanosis of fracture dislocution. I sent him to the hospital, gave lim nn ancsthetic, and on manipulation found a fracture at the surpical neek of the humerus and anterior dislocation. I was malble to reduce his dislocation, so put the arm up in as good position as possible, and when the patient had recovered from the ancisthetie ndvised him to let me operate and put his arm in proper position. This he refused to do and went home. l axamined the patient on May 1. He said that he had no pain, but he conld not move his arm very mueh. although his movements were greater than when lie left here. He had no adduction and very little abluction, anterior and posterior movements were good. He still declines operation, because, as he say's, "Mly arm doesn't hurt me and I am getting better all the time."

(Ase 2.-History.-.The patient, who was referred to me by Dr. H. on Fehruary 18, suid that the last he remembered was that be was standing at a lunch-counter drinking coffee: a policeman told him he fell over and had a fit and that they picked him up and walked him home. This was on Nov. 2 1909. A physician was sent for on November 3 , who anes thetized the patient and put his arm in splints. Not having obtained any use of his arm, the patient went back to the physiciun on December 3, and was again given an anesthetic and the dislocution supposedly reduced ngain. This time the arm was put up in plaster of Paris; the splint wis left for three weeks and then taken off. The arm was still severcly painful and useless.

Examination, 'reatment and Result.-.0n careful examination, including the use of the $x$-ray, 1 found a retroglenoid dislocation with fracture of the anatomic neck of the humerus. I advised operation and on Feb. 22, assisted by Dr. Edwards, J. opened the joint, using the anterior incision. took ont the heal of the bone, curetted the glenoid cavity and put the arm up in position, kept it immobilized until the wound henled, and since then the patient has hat constantly passive and netive motion with massage and as a result is getting good use of his arm. I believe that if I had used the posterior incision I would have had less difficulty in removing the head of the humerus.

In comparing my two eases I find that the patient on whom I operated has the most serviceable arm and therefore, I should advise all persoms who have dislocation of the humerus with fracture in which reduction has not been obtained and there is restricted motion to submit to an operation.

All patients with unreduced retroglenoid fracture dislocation should be operated on, using posterior intermuscular incision recommended by Dr. W. G. Spencer.

\section{THE CONTRIBUTION OF EXPERIMENTAL TO HUMAN POLIOMYELITIS *}

\author{
SIMON FLEXNER, M.D.
}

NEW YORK

Epidemic poliomyelitis has within three years become a common and widely distributed disease in the United States. Prior to 1907 the epidemic disease occurred rarely, only, in this country. Since 1907 it has prevailed from the Atlantic to the Pacific Ocean, and probably few states have entirely escaped its ravages. Judging from the fragmentary reports which have come to my attention it would secm as though the southern states had escaped wholly or in large part, but this apparent discrepancy may result from failure either to recognize the nature of the epidemic disease or to report on it, or may be due simply to the circumstance that the fact of its oceurrence in the South has not chanced to come to my attention.

* A rnther complete blbltography accompunied this article and is included in the author's reprints. Because of the space reguired, it is omitted from 'THb Jounsal. 
It is significant in respect to this point that within the period mentioned epidemic poliomyelitis has prerailed in Cuba. Before $190 \%$ epidemic poliomyelitis had been becoming more frequent in northern Europe and particularly, so far as reports indicate, in Scandinavia. Beginning in $190 \%$ or thereabout a pandemic of the discase arose. 'The United States, Anstria, Germany and latterly France have cortainly participatod in the gyidemic nuthreaks. Whother still other countries have been similarly visited I camnot say, but it is highly probable that they have.

It is a matter of significance that the original foci of the epidemi: disease in the United States. occurring in the summer of 1907, were anong the Atlantic seaboard, and that the two centers of population most seriously affected were about Greater New York and Boston. The particular point of importance in this regard arises from the fact that those two centers of population receive first and in most concentrated way the immigrant population from northern and eastern liurope. Since, moreorer, the best established endemic forus of epidemic poliomyelitis recorded in the last decade or two has been the countries of Scandinaria, the further fact becomes significant that the second largo isolated outbreak of the disease in this country occursed in that part of the middle west, mamely about Minnesota, which receives a large influx of immigrant population from Norway and Sweden.

\section{CONTAGIOUSNGSS}

The studies especially devoted to the question of the mode of spread of poliomyelitis, which lrave been conducted with unusual energy and perspicacity in the last few years, would seem to have rendered contagion highly probable. If the views respeeting the manner of the transfer of the contagion put forward with good reason should become established, the explanation of the extension of the epidemic centers of polinmyelitis from north. ern Europe to America wil] have become obvious. The data collected in Scandinavia indicate that the contagion can be calried by intermediate persons from the stricken to the healthy, and from patients not frankly paralyzed, but suffering with slight or so-called abortive attacks of the disease. Moreover, the incubation period of the disense would appear to vary within considerable limits, being sometimes not more than two or thee or four days in length and at other tinres as mueh as twenty days, the averugre being eightic or ten days, and thus aflording opportunity fol the transportation across the Atlantic Ocean of the incipiontly infected. 'This particular problem would receive considerable illumination from facts which arc ascertainable, such as the number approximately of recently arrived immigrants who developed poliomyelitis in this country since $190 \%$. I am not aware that any effort has been made in the course of the scveral recent extensive investigations of the epidemiology of the affection to elucidate this important point.

The idea of a contagion in respect to epidemic poliomyelitis is not a new one, but appearer in the literature mow: than a quarter of a century ago, and of late has been frequently invoked. The clinical course of the diseaso indicated an infeetious origin. but up to very recent times an convincing. knowlelge concerning the nature of the agent causing epidemic poliomyelitis existed. Tarious bacteria, and especially certain cocoi, have from time to time been isolated in cultures from fluids obtained by lumbar puncture from patients suffering f's'om the epidemic disease, or from specimens of the central nervous system removed from victims at antopsy. These bacteria did not conform to one spexies or group of mi(co-organisms, and did not suffice to sed up poliomyelitis in animals. 'They can be aceounted for more satislanctorily as contaminations of secondaldy invading bacteria than as the caluse of the discase. T'Je epidemic of toge in this country, in France and in ciermany, hel to a renewed study of the mature of the infection, in the compere of which the more subtle and recent methods of burteriology were employed. These mothods lod almost simultmes ously in the United states by 1)r. Tewis and mysell and in france by Iandsteiner and levaliti, to the discovery that the jutections agent was an extremely mimte microolganism that readily passed throngh the pores of enthenware filters and constituted, therdole, an example of the so-dalled filternble rimses, of which at the present time several examples are known to camse infections disenses in man and the lower animals. 'Tle? filterable nature of the virus has now been confirmed wherever the subjed has been acomately investignted. On acequisition of the fact of the mature of this vilus, and of the further lant, on which the discovery of thes nature of the virus artually depends, that lioth the higher and lower monkeys are snbjeet to the experimental diserse, rests the reent great adrances which have been made in the investigation of epidemic poliomyclitis.

\section{EXPlRIMEN'S WITT MONKLYS}

It was predictable that the aflort would be made as soon as circumstances favoled to transmit poliomyelitis to monkeys. Since the disease appeared not to be transferable to the more common species of warm-blooded animals, usually available in laboratories, it became imporative to attempt jts transfer to other species more nearly related to man. The last few years had indecd afforded several brilliant instances in which progress in detemining the nature or the conquest of important infectious disenses lind resulted from the use of apes and monkeys. 'Two examples illustrative of this statement are afforded by syphilis and epidemic cerebrospiual meningitis. Hence, in $190 \%$, when the first epidemie appeared in New York and vieinity, we endeavored to transfer poliomyelitis from hmman beings to monkeys. Tnfortunately we were at this time limited merely to fluids obtained by lumbar puncture from cases at different stages of the disease. I say unfortmuntely for the renson that we had the iden orjginally of loringing the supposedly infected material directly into relation with the nervous systems of monkeys. 'jhis we jucled did with the fluids obtained by lumbar puncture, from which we failed entirely to produce any symptoms that we conld discover, including paralysis. Buring the epidemic of $190 \%$ we did not secure organs from a case of pure inlantile paralysis, and we failed, therefore, in onr intention to inoculate monkeys from the spinal cord. Had we secured such material the discovery of the nature of epiclemic poliomyelitis would, it is fair to assume, lauve been made two years earlier than it was. Jit was not until Septimber, 1909, that we sectured the spinal coril from two anses of infantile paralysis in humnn beings, which specimens were employed for the inocula. tion of monkeys by direct injection of an emulsion into the brain through a trejhine opening. The first inoctlations were successful. 'The animals immediately after' their lecovery from the ether anesthesia were lively and normal. 'lley remained apparently in perfect henth for' a number of days, when paralysis set in. The spinal 
cord derived from these animals was and is still being employed to transmit the infection to still other. monkeys.

During the summer of 1909 Landsteiner and Popper published an account of a successful inoculation of two monkeys with the spinal cord derived from a case ol: infantile paralysis in a elild. 'They employed the peritoneal cavity as the site of injection, which led to the development of paralysis, but in endeavoring to continue the transfer of the virus by intraperitoneal injection of other monkeys they failed entirely. Strauss and Hum. toon in this conntry, who repeated in the late summer of early antumn of 1909 the experiments of Landsteiner and Popper, met witl the same interruption of thris work. Using the peritonem as the avenue of entrance of the virus, they succeeded in producing paralysis in a monkey inoculated with the limuan cord, but failed to proluce paralysis when they transfered to other monkexs a suspension of the spinal cord of the pallalyzed monkey. In view of these experjuments, and of still other similar ones made by different investigators, it is probable that the virus contaned within the hmman cord is on the whole more active when implanted in the monliey than is the virus contained within the monkeys' spinal cords that is derived by proliferation immediately from the virus of liuman source. The question for the moment renains open whether this disparity depends on the quality of the virus or the number or state of concentration of the organisms. Later studies, to which reference will be made, incliente that the virus of poliomyelitis is subject to qualitative variations, from which it follows that the sudden change of host might tend to a reduction in the potency of the virus, the fact of whicl) leduction is exbibited when the virus is compelled to traverse a considerable territory and to over'ome certain natural obstacles before it reaches the central nervous system, on which it became implanted. The fact of this qualitative change is far less apparent when the altered virus is brought inmediately into relation with the tissues of the nervous system.

\section{CLINICAL EFELCTS OF INOCULATIONS}

In noting the clinical effects of the inoculations we lave paid attention to a number of conditions and signs that had aljeady been indicated by observations made on the human affection. We have, therefore, observed an incubation period represented by the interval clapsing between the time of inoculation and the appearance of the first definite paralysis, which incubation period includes certain manilestations which have been noted as prodromal symptoms. Thus the shortest period noted as elapsing between the inoculation and the onset of paralysis has been three or four days and the longest period thirty-three days, the average period being eight or nine days. 'The prodromal symptoms consist of a state of unduc nervousness and excitability on the part of the inoculated monkeys, or inability to fix the gaze, with which is associated a wrinkle and mobile rather than sniooth and placid 'ast ol' countenance, and an erection of the hairs over the body. 'These symptoms are most marked for a period of from six to eight hours before the onset of the paralysis. We have not noted any constant elevation of temperature or gastro-intestinal disturbance. The onset of paralysis either when the prodromal symptoms have occurred, or when they have been absent or undeterted, tents to be sudilen. The par'alysis afiecting any of the larger groups of voluntary muscles tends to be accompanied with other weak or partially paralyzed groups of muscles. In certain animals the medulla was first affected, and in them death sometimes oceurred before the development of actmol paralysis, In respect to location, the lower and upper extremities were affected oftemer than the muscles of the rrunk, and the spinal paralyses were much more frequent than the cerebral. Sensory disturbances ocenred, but their investigation was nuch less satisfactory than the investigation of the motor disturbances. In other words, there is a striking similarity between the fank examples of epidemic poliomyelitis, whether occurring spontaneously in man or produced experimentally in nonkeys. A further colrespondence exists in this: Slight and aranescent or abortive attacks of the disense have been described in human beings, enses the nature of which would not he suspected were it not for the fact that they oceur during the prevalence of epidemice of frank paralysis: and similar abortive or cvanescent attarks have been noted among inoculated monkeys, but rarely. There is, however, one inportant point in which the experimental discase happily diflers from the human affection. The mortality in the human affection rarely excoeds 10 per cent. of those frankly attacked, and fropuently it is much less than that. The experimental disiase, on the other hand, has terminated fatally in about one-half of the first serjes of animals inoculated, and in a much larger proportion of the later ones. Hence the experimental disease is more highly fatal than the spontaneous disease.

\section{PATHOLOGY}

A still further corres]ondence between the spontaneous and experimental discuse is found in respect to the pathologic changes or lesions. The gross lesions visible to the naked eye present in the spinal cord and medulla of monkeys consist of congestion and hemorrhage into the gray matter, chiefly but not exclusively confined to the anterior horns. On the other hand, the general appearance of the spinal cord, mednlla and brain arc not greatly altered, and the visible effects are no proper measure of the damage inflicted by the virus.

'The microscopic lesions are more severe and widespread in the spinal cord than in the brain, and more pronounced in the gray matter and membranes of the cord than in the white matter. No part of the spinal cord, inchuding the medulla, is entirely free from lesions, but the severest lesions tend to occur at levels corresponding to the groups of museles most severely paralyzed. 'The nreninges show nore or less diffuse infiltration with round cells; the greatest accumulations of which are about the blood-vessels, where thick collars of cells often exist. The infiltration is within the adrentitial coat, while the muscular coat and the intima remain intact; although the lumina of the vessels are often encroached on through compression. When the vessels are small the effect on the lumina, and hence on the permeability, are considerable. Meningeal cellular invasion is always interstitial and does not give rise to cxudute on the surface of the cord or brim, and it is, morcover, made up almost exclusively of mononuclear cells.

The gray matter of the cord shows lesions of the anterior and posterior horns and the commissure, but the anterior horns are as a rule more severely and wilely injured than the posterior looms. The chief lesions surround the vessels and consist of a cellular iufiltration 
and edema of the perivascular spaces, and sometimes of hemorrhages as well. When the nerve cells and ground substance are injured, as is frequently the case, foci of similar cells occur there, and the nerve cells show degen. erition and necrosis. 'The extent of the lesions in the gray matter varies greatly. Sometimes minute foci of injury and sometimes complete degeneration of the anterior horns occur. 'The infiltration of the perivascular sheaths of the vessels is continuous with that of the pia-arachnoid. The white matter of the cord holds in respect to the frequency and severity of the affection an inferior position, and the lesions when present there consist of edema, perivascular cellular infiltration, hemorrhage and necrosis of tissue. 'The brain shows lesions that are, however, more sparse than in the spinal cord. They correspond with cellular infiltrations of the meninges simjlar to but less in amount than in the cord. 'The intervertebral ganglia regularly are the seat of a diftuse and nodular infiltration with lymphocytic cells, which collect between the nerve cells and about the nerve fibers, both of which may be the seat of degeneration or of neerosis.

The pathogenesis of the affection is explained by the nature and distribution of the lesions. It would appear that the virus becomes implanted on the leptomeninges, especially in the region of the spinal cord and medulta, where it sets up-cellular infiltrative changes that are most marked in the perivascular lympl spaces of the arteries entering the nervous tissues. I'he vascular Jesions constitute the primary canses of the lesions of the nervous tissue, the severity of which is determined by the particular vessels affected and the intensity of the involvement. The infiltrative lesions are ronfined to the perivascular lymph sheath and adventitia, but still other lesions must occur in the intima of the vessels from which the edema and hemorrlage arise. The central arteries entering the anterior median fissure and supplying the anterior giray matter of the cord invariably become affected, through which the preponderance of lesions of the anterior horns is accounted for. Since the arteries supplying the posterior gray matter are less important, the lesions in the posterior cornua are slighter. The degree, therefore, of aflection is determined by the richness of the arterial blood supply, whence is explained the liability of the lumbar and cervical enlargements to severe Jesions. Irregularity in the branching of the central artery probably explains the common varjations observed in the involvement of the two lateral halves of the body. The brain is far less commonly the seat of lesions, but it is not spared. Paralysis of the eranial nerves, and especially of the facial nerve, follows on them, but lesions also occur in parts of the brain which do not respond by paralysis. The brain injuries, like those of the cord, depend on vascular lesions.

Hence it would appear that there are good grounds for believing that a considerable part of the paralyses, especially those that are not permanent, are the eflects of temporary vascular impediments. The impediments are all outside the lumina of the vessels, which are merely reduced in caliber through pressure. 'Thrombi do not occur. Some of the functional disturbances are possibly thus anemic in origin; others are probably caused by slight degenerations, and still others are undoubtedly caused by focal hemorrhages and edema. All these effects may possibly be recovered from: part by resolution of the cellular vascular infiltrate and reestablishment of the lumen; part by absorption of edema and hemorrhage, and part by restoration of the mildly degenerated nerve cells. The severer degenerative and otler lesions, through which actual necrosis is produced, do not become restored. On them depend the permanent paralyses and deformity.

\section{THIE VIRUS}

The vilus causing epidemic poliomyelitis has been stated to be of very minute size. It is, so far as we can now judge, one of the most minute organisms lnown to cause disease. This conclusion follows from the fact that in aqueous suspension, such as is sectured through preparing an emulsion of the spinal cord in clistilled water, it passes with great readiness and little ol no loss of jotency through the pol'es of the densest and finest porcelain filters, namely, the so-called Chamberland filter. It passes with even greater case through the somewhat less dense Berketeld filter. It is extremely doubtliul whether the virus has actually been seen. On staining filun preparations of the filtrite with mordanting dyes, preparations are secured which under the highest powers of the micioseope exhibit minute points, circular or slightly oval in form, which posibibly, although not ecrtainly, represent the stained parasile. When tỉe filtrates are examined under the dark microscope, jnnumerable bright dancing points, devoid of definite sime and form, and not truly motile, ean be discerned. That these particles represent the micro-organism of poliomyelitis connot be aftirmed, since similar partirles are present in filtrates obtuined f'rom nervous and other tissues which can be viewed also as consisting of simple protein matter.

The filtrates aro highly potent. Qumutities as small as one one-thousandth to one one-hundredth of a cubie centimeter sulfice to anse paralysis in monkeys after the nstal incubation period, when injected into the brain. 'I'ha virus is highly resistant to external agencies and conditions. It withstunds glyeerination for weeks or months very much as the virus of raceinia or rabies cloes. It withstands ilyjing over caustic potash for weeks without any or marked reduction in potoney, showing a grenater degree of resistance than the virus of mabies. 1t retains its virulence apparently unimpaired for weeks, on being kept constantly fromen at minus 2 to 4 . C. It also withstands for a long lime temperature slightly above the freesing point of water, in the coul'se of which the nervous tissue containing the virus undergoes autolysis, and it has been shown to survive the growth of ordinary mould. On the other hand, it is readily injurel by heating. since temperature of 45 to $50 \mathrm{C}$. maintained for hall" an lour sulfices to render the fittrate incapable of cansing patralysis. It is also readily destroyed by 1 per cent. solution of hydrogen peroxid, and by such simple disinfectants as menthol.

'That the virus is a living organism must be concluded from the faxt that such minute quantities of it suffice to carry infection through an indefinite series of animals. We have propagated the virus now through twenty-five generations, representing twenty-five separate series of monkeys, and as many lemoves from the original human material supplying it, and the activity of the virus for the monkeys has increased rather than diminished in the course, and as the ressult ol the successive transplantations. Whether the vinus has been or is to be cultivated outside of the body is still an undecided question. We enly secured certain indications which led us to lope that the virus multiplied in a medium of bouillon mixed with human serum. We have, however, not succeded 
in producing paralysis by the inoculation of one of these josisible cultivations. On the other hand, original virus has been observed to retain its virulence for several weeks when kept in a similar bouillon at the temperature of the thermostat.

\section{PIROGNOSIS}

At the outset of the experiments we estimated that less than one-laalt of the monkeys that became paralyod would, if permitted, recover more or less completely from the paralysis. Since, however, our purpose was best scrved at the time by sacrificing the paralyzed animals immediately on the appearance of the paralysis, they were as a rille etherized. We now believe that the deduction was erroncous and that the fatalities would lanve been greater than we supposed, and probably as many as three-fourths of the paralyzed animals would have suecumbed to the disease. At this early period, however, a number of paralyzed animals recovered, nsually, lowever, incompletely, retaining residue of the paralysis similar to. what is observed in the spontaneous human affection. The indications now are that the virus has altered qualitatively and so increased in potency in the Jater generations that jecoveries are lardly to be looked for'. The mortality at present approaches 100 per cent., with which figure there is happily nothing in the pathology of the human affection that is comparable. In view of certain cxperiments of a therapentic chararter which are to be mentioned, the fact of the intense activity of the virus should be borne in mind. Tndoubtedly examples of the virus will be discovered which will become modified in the reverse direction and lose rather than gain in activity. At one period, indeed, in the comese of propagation of ench of the.two viruses which we originally secured there occurred what appeared to be a sharp decrease of vilulence, a change indicated by freble effecets during several paissages and the final loss of power of certain strains to transmit the infection. 'T'o the circminstance that we carried the virus forwarl in jalallal series of inoculations is to be attributed the survival and incleasing activity of the strains at present in lise.

\section{INOCULATION OF O'HIER ANIMALS}

Repented attempts have been made to implant the vijus on other animals, but without success. ' 'Jhe animals thus employed consisted of the available warmhlooded domestio animals of this country, and included suinea-pigs, Jabbits, rats, mice, dogs, cats, sheep, cows; roats, pigs, chickens, pigeons and horse. 'J'he rabluits and guinea-pigs were inoculated directly with each of the two suecimens of hmman vious, and alditional rabhits and guinca-bigs and other animals with virus derived lom monkeys. In eontrist with these failures is the sucessfinl employment of several speeies of monkeys. 'The greater number employed were of the speries Macreus vhesus but all other species of old world monkeys secm equilly suseptible. 'These included, beside M. rhesus, M. Cyonomolgus and nemestrimus, Cercorebus fulignosus, Cercopitherus callitrichus, and Papio babuin. () the now world monkeys we employed two species, one helongines to the remus (eplus and the other including Capuchinus. It chanced that the larger ring-tail proved susceptible and the smaller did jot, so that a question arises whether tho catarline are not more uniformly susreptible than the platarrhine species. No instance of

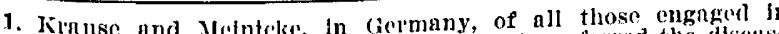

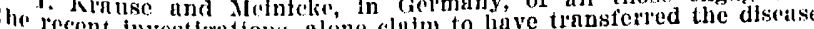
to rabbits. the spontaneous transfer of the virus from a paralyzed to a normal monkey arose, although many opportunities for contagion in the course of our many experiments occurred. This fact does not militate against the notion of contagion in respect to the spontaneous disease in man, for the reason that the monkey is obviously under ordinary conditions and beause of the possession of adequate external means of defence an insusceptible species, although once these defences are surmomnted it proves less able to resist the injurious effects of the virus than human beings.

\section{MODES OF INFIETION}

We have secn that the intracerebral mode of infection is not the only successful one, and that the virus may be introduced into the body by way of the peritoneal cavity under ciremustances leading to paralysis. It has been proved that the virus, when derived from an infected monkey, may also be introduced successfully by way, not only of the peritoneum, but also by means of the general blood, the subcutis, spinal canal, large nerves and certain mucous surfaces. Thus the introduction of large quintities of virus into the stomach or duodenum does not lead to paralysis unless the motions of these organs are for a time arrested by means of opium. When perjstalsis has thus been prevented infection and paralysis result in some instances after this mode of introduction of the virus. However, it would appenr that none of the avenues mentioned lead so uniformly to paralysis as does the direct or intracerebral mode of inoculation into the nerrous tissues. 'J'here exists, however, one mucons sulface that is more readily traversed by the virus than the other avenues, excepting the brain, and that is the mucosa of the nasopharynx. If this mucous membrane is lightly scarified in an etherized animal, and the virus rubbed into the scarifications by means of a swab, infection and paralysis usually, and with few exceptions, results with promptitude. Our experience is to the effect that the tracheal mucosa and the lungs do not aflord an easy point of entrance of the virus into the body, at least under conditions in which gloss lesions of the superficial tissnes have not been previously produced.

'l he facts just given concerning the several possible portals of entry of the virus of poliomyelitis into the body under conditions leading to paralysis have significance with respect to the usual portal of entry of the poison in the spontaneous infection in man. We have been led by certain theoretical considerations to view the nasopharynx as the location in the body to be regarded with special suspicion as being the portal of entry of the virus. Some of these theoretical considerations may be mentioned. Our attention was arrested by the frequently observed fact that in point of distribution epidemic poliomyelitis resembles epidemic cerebrospinal meningitis, and that the two riseases, indeed, so often presented such close similarities in this respect that they had often bren confounded with each other. 'The chiel and strikjng difference between them related to the seasonal prevalence, which for epidemic poliomyelitis is midsummer and for epidemic cerebrospinal meningitis late winter or early spring. 'Jlie two discases, moreover, attack by preference infants and young children, although not sparing older eliblden and arhults, and in about the same ratio. In the majority of instances a single case appears in a family or home, but often two cases, and less olten thue or more cases appear. The relation between the group cases in a house or locality has in respect to both 
discases been made out only recently, through the discovery of the role of the intermediate carrier of the infection.

Now it is held that the Diplococcus intracellularis jasses into the cerebrospinal membrane by way of the Jymphatic connection existing between them and the jasopharyngeal mucous membranc. None of the lower animals, not even monkeys, are so susceptible to the pathogenic effects of the Diplococeus intracellularis that its inoculation into the nasal mucosa suffices to set up acote meningitis. We have alpeady seen that the virus of polionyelitis, which is so much more active, can be introduced successfully by direct inoculation into this membrane.

The considerations thus far given show the close agreement existing between the two disenses, epidemic menjngitis and epidemic poliomyelitis, in respect to the part played by the nasopharyngeal mucous membrane. Still other considerations are these: It is difficult, if not jupossible, to establish in human beings the fact that the diplococcus passes from the meninges by a reverse lymph current into the nasopharynx, and yet such a migration is not only highly probable, but would nost readily and sutisfactorily explain the persistent intracellularis in lection of these mucous membranes, which is regularly present in epidemic cerebrospinal meningitis. The ease is quite different in monkeys infected with Diplococeus intracellularis by injection of cultures into the lumbar spinal canal, in wlich the migration into the nasopharynx of the diplococous contuined in Jerkocytes, and free also, has been followed with the microscope. It may therefore be regarded as established that this mucous membrane serves both as the site of escape from and of entrance into the meninges of the Diplococcus intracellularis in man. 'The question arises: Does this membrane serve a similar double function in respert to the virus of poliomyelitis? 'That it may serve for its entrance into the bolly we have already seen, and the experiment is readily made to determine whether or rot the virus is also excreted there. The excised mucosa of monkeys recently paralyzed and killed has only to be rubloed up with quartz sand, suspended in distilled water and pressed through a porcelain filter in order to secure a fluid free from bacteria and suitable for inoculation into the brain of healthy monkeys. By employing this method we have been able to produce paralysis, and thus to prove that the mucous membrane contains the virus. 'The virus in the mucous membrane is not derived firm the blood contained within it. It is true that the blood does contain the virus, but in such minimal quantities that an amount of two cubic centimeters may fail to cause the infection, while as much as 20 has caused typical paralysis. Moreover, we lave ascertained that - the organs generally do not contain the virus in such amounts as readily to convey the infection. We have failed repeatedly to secure infection from the spleen, bone marrow, liver and different groups of lympliatic glands, and in severnl experiments failed to develop paralysis after injection of the salivary glands, alt?ough Tevaditi : has leported one such successful experiment umomg several failures. We have failed to produce paralysis by the injection of a suspension of the mesenteric lymph nodes taken from an animal that had beeome farnlyzed as $n$ result of an intrastomachic injection of the virus, while we have been successful in producing jelralysis with the mesenteric lymph noles secured from - Inman case of poliomyelitis. That the lymphatic glands in the monkey are capalole of retaining the virus in an active state is proved by the fact that after subcutaneous inoculation of an emulsion of the spinal cord derived from a paralyzed animal, the regional lymphatic glands (axillary and inguinal) proved infectious. $\Lambda$ gain, Römer and laciner and Wiesner have in certain instances caused paralysis by injecting into the brain emulsions of the mesenteric and of the cervical lymphatic glands taken from monkeys which became paralyed following an intra-cerebral inoculation of the virus. It appears, therefore, that the virus may be retained for a time by certain distant organs, and especially by the lymphatic glands, which it reaches through the general circulation; but these localizations give no indication of the point of entrance into the body of the virus. The virus has thus fal not been found in the excreta, that is, in the feces and wine, nor in the intestinal mucosa or bile. Since the virus is filterable it is possible to demonstrate its presence in material highly contaminated with bacteria.

We are disposed to the view that the nasal mucosa serves not only as the portal of infection but also as the path of elimination of the virus into external nature, since such elimination must ocom in order that the virus be maintained alive and transmissible: It is well known that direet connections exist between the meninges and the nasal mucosa by way of the lymplatics, which jass with the filaments of the olfactory nerve through the cribriform plate. We have already alluded to the fuct that the virus first becomes implanted on the leptomeninges, and this primary location of the virus is what would be especially favored by the mode of entrance of the virus just mentioned. 'That the early participation of the leptomeninges does not necur without certain definite corresponding alterations taking place in the cerebrospinal fluid we lave been able to demonstrate. It will be recalled fiom the cerelorospinal fluid obtained by lumbar puncture from cases of the human spontaneous disease at different periods after the onset of paralysis, have shown only slight qualitative abnormalities. 'These fluids, which are clear', but may be in exeess, show morely a moderate increase of the lymphocytes normally present, and no other qualitative changes. Moreover, this fluid has been shown by repented tests to be non-infectious, or at least not capable of setting up paralysis in monkoys, even when injected into the brain. In monkeys on the other hand, in which the spinal fluid can be investigated during the inculontion period of the disease, as well as after the development of paralysis, it has been slown that the reaction of the meninges to the injection of the virus occuls quickly and that at the expiration of periods of twenty-four, forty-eight or seventy-two houls, the number of eells within the fluid las progressively increased, so as to give rise to a slight opalesence of the fluid which becomes subject also to spontancous congulation. The fluids contain an cxess of protein, as may be shown by means of Noguchi's butyric actid test. This condition of incrensed cells and protein is of brief duration and is succeeded by one in which the fluid is clear and non-congulable and the protein not increased, but only the lymphocytes are more numerous than normally. This is the state of the fluid in monkeys at a period concul'ung with the onset of paralysis, or appearing soon after, so that there is essential agreenent between the two conditions. The spinal fluid taken from monkeys when clear and limpid, does not convey the infection and produce paralysis, but when 
the fluid is talien at an earlier period, at the height of the opalescence, it is capable of transmitting the disease.

Finally, the question arises whether the virus of poljomyelitis can be directly implarted on the leptomeninges, which question can be answered in the affirnative. If an active virus is introduced by lumbar puncture into the meninges, infection and paralysis may be produced. Hence it would aypear as though all the theoretical conditions recuired to establish the nasal and meningeal route as a direct one for infection in poliomyelitis had been supplied by experiment.

It remains to add that in course of the demonstration given by these experiments, two important subsidiary problems have been elucidated: First, the pathogenesis of the affection has been rendered clear and comprehensible, and next the changes in the spinal fluid induced by the infection have been brought clearly into view as constituting ejiteria on which, even in human cases, an early diagnosis of the lisease, preceding the onset of any meningeal or paralytic symptoms, nuy come to be based. What is required merely is that those plyysicians having access to clinical cases should perfor'm lumbar puncture early when poliomyelitis is suspected, and during the prevalence of an epidenic on patients presenting a series of indefinite symptoms that precede as prodromata the onset of paralysis, or themselves comprise the group-symptoms that may define the so-called abortive form of the affection.

\section{INMUNITY}

Experiments luave been conducted to determine the kinds and degrees of: immunity which are produced by the inoculation of the virus of poliomyelitis. Since the liternture on epiclenic polionyelitis is silent on the subjeet of reinfection, it can be inferred that a second attack of the disease is rarely ever suffered by one individual. Two possible reasous can be assigned for this: 'The first and most probuble is that one attack of this disease, as is the case with some other acuite general infections, tends to afford an enduring immunity, and the other, that as epidemies have in the past occurred infrequently and reappeared after long jntervals, the children once affected have passed beyond the susceptible age period at the time of the next epidemic.

We have available in monkeys which have recovered from an undoubted infection, attended by paralysis, an opportunity to decile the question whether an attack of poliomyelitis protects against subsequent infection. Thus far we have subjected a number of monkeys to reinoculation into the brain at periods varying from cight days to four or five months, after the paralysis first appeared, without succeeding in reinfecting any of these animals. 'They were not rendered perceptibly sick by the subsequent inoculation after the one originally producing paralysis, and in no instance was recrudescence of the paralysis produced. It is interesting to note that in point of severity the first attack varied between mere tremor of the head, a partial paralysis of one limb, and complete paralysis of legs and arms. The paralysis had in some instances nealy or completely disappeared, and in others it had become reduced, but still affected all the muscles of one or two limbs. 'These results indi-

". The enrlest cellular renction in monkeys is not purely

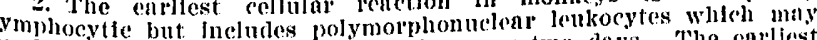

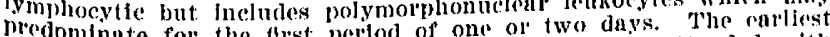
lindominnte for the first poriod of one or two is attended with lonetion of the moutuges lin human beings nlso cate what will probably be found to be true equally of human beings, that an uncloubted attack of poliomyelitis, even when unaccompanied by definite paralysis, produces a state of refractoriness in reinoculation with active virus that endures for months and probably for years, if not throughout the life of the affected individual. On the other hand, our experiments, embracing now a Jarge number of monkeys, establish that when the virus is introduced into the brain, practically all monkeys belonging to the generally susceptible species are subject to infection, although they do not invariably suecumb to the first inoculation, but may require a second injection. However, it wonld still appear that rare individual monkeys are highly refiactory to infection, and it has also been observed that an unsuccessful inoculation of the virus does not act as a protective, but leaves the unatfocted animals either with their original degree of susceptibility unimpaired, or, what further experimentation will be needed to confirm, leaves the animals possibly somewhat more disposed to a subsecyuent infection.

'This latter point of the failure of an unstlecesslul intracerebral inoculation of the virus to inclease resistance does not answer the question negatively, whether by suitable means it may not be possible to develop an active immunity independently of the production of even the most trifling symptoms that might be taken to indi(ate an attack of poliomyelitis. We have, indeed, been successful in establishing in a certain number of monkeys a state of active immunity through a single large subcutaneous injection of the crude or modified virus, as represented by the emulsions of the spinal cord taken from recently paralyzed monkeys, or by repeated injections of gradually increased amounts of the crude virus. This mode of producing active immmity has not, np to the present, been developed into a uniformly suceessful and safe method, since of the treated animals some do not develop a strong immunity and otlers develop palralysis as a lesult of the treatment. The direct immunizing effect has been produced also by means of a virus somewhat modified after a long immersion in glyrerin, so that it may be regarded as probable that a qualitatively modified virus, changed through the action of chenical or physical agents, or modified by biological conditions within certain hosts, can be produced, and that this altered virus will be found more appropriate than the virus of full potency for purposes of active jmmumization. At present the experimental basis is entirely inadequate to justify the attempt to induee active immunity as a protective measure in himman beings. Monkeys thus directly immunized resist successfully the injection of large doses of vilus into the brain.

It lias therefore been established that an undoubted and even high degree of immmity to infection with the virus of poliomyelitis is obtainable in animals, and probably equally in human beings. The question which next arises is this: As a result of this immunity, do the boly fiuids acquire new properties capable of experimental demonstration, on which the immunity probably depends? In answer it can be stated that human beings and nonkeys who have passed through an attack of poliomyelitis come to contain in their blood certain nentrulizing principles for the virus of poliomyeitis, and that these principles are readily demonstrable by animal tests for two or more years in lumman beings, and that they probably persist for as great a period in monkicys. similar principles are absent from the normal serum. 
'Tluey are demonstrater by bringing into contact an active filtrate containing the virus with the serum of the blood derived from animals of luuman beings who have decovered froms poljomyelitis, or from monkeys actively jmmunized directly to the virus, and incubating the mixture for a period at 39 ( $!$ and determining that after this treatment the virns is no longer able to set up juralisis on being injected into the brain of normal monkeys. I'unthermore, it has been shown by Netter and levaditi that the blood of a patient who had suffered an aboutive attack of poliomyelitis contained such nentralizing principles.

$\Lambda$ pressing question rould now be approached, namely, whatles the immunity principles contained within the serum suffice to newtralize the vilus of poliomyclitis once it is present in the holy. It could be assumed that the selum of animals, ats of human beings that had recovered from paralisis. would contain the immunity junciples in no high state of concentration. Effort was therefore made to reinfore the legree of immunity in these monkeys by subsequent inoculations of virus, and the theranentic experiments defined were conducted in part with this reinforeed serum, and in part with the crum of directly immunized monkeys, and such serum is could be obtained from liuman patients. It can now he stnted that if the quantity of the virus injected into the brain be not in excess of a given dose the development of poralysis can in some cases be prevented by makjow several jnjections of the sernom by lumbar puncture into the subarachmoid space, while in another number of mimals the onset of paralysis is much delayed. In Jespect to the latter proint it may be stated that the jeriod of incubation in the control animals ranged from swon to eleven dars, and in some of the animals treated rith the human sermo the onset of paralysis was delayed until the twenty-sixth or iwenty-seventh day. Morescer, infection by the nasal mucosa can also and with irater certainty be prevented by the serum injections.

'The manner of making the therapentic injections was comewhat varicd, but in general may be described as follows: An intracerelorl injection of the virus having been made, after the expiration of a period not exceeding fwenty-four hours, the subaraclunoid injections of the serum were performel on three successive days, after which, an interval of three days having been allowed to clapse, three more daily injections of serum were given. lle chose the subarachoirl mothod of injection rather than the intravenoms morle, in order that the immunity winciples might be brought into the most direct relationship with the virus, and particularly in view of our conception of the pathogenesis of poliomyelitis and of the primary site of locialiation of the virus in the leptoJoneninges. We beliove that as good results could not be andieved by the intravenous injection of the serum, althongh the immunity principles could doubtless be brought to the newvous tissies loy the circulating blood, for the reason that we know that these principles are not readily it at all secreted into the subarachnoid space. Jence they would not come into relationship with the seat of the active virus at a period preceding its active proliferation and extension throughout the nervous tissues. We think it also probable that had the serum injections been resumed after another interval of rest, the last vestiges of the virus in the tissues might have hean destroyed in those animals in which the incubation joriod was much delayed, so that the ultimate appearance of paralysis might have heen entirely prevented.
We have sought to ascertain whether animals protected from infection through the employment of mixtures of virus and jmmune sera, or as a result of treatment by subarachnoid injections of immune sern for therapentic purposes, exhibited an unusual degree of resistance to subsequent intracerebral injections of active virus'made. at periods of several weeks to four or five months after the conclusion of' the original experiments. 'I'he object of these tests was to ascertain whether a permanent augmentation of the natural resistance to infection had been accomplished by the introduction of the virus under these conditions of restraint into the boly. We lave found that no unusual degree of resiatance to subsequent intracerebral injections of active virus las resulted, which fact we believe points to the validity of the following deductions: (1) A neutralized mixture of virus and immune serum does not lead to any degree of active immunization; (2) the therapeutic action of an immune: serum is associated with restraint of inultiplication of the virus such as would be required to establish any grade of actire immunity; (3) a simple passive immunity is either not produced at all by the serum injections, or is of brief darition or small amount.

\section{PRODUCHON OF A SERUM}

The observations on immunity which have been presented early suggested that an effort be made to produce a correspondiug active immunity in some of the lower animals that might jossibly become the source of a therapentic serum. 'This particular phase of our studies is being actively pursued at the present time. However, several facts have already been developed. It has, for instance, been found that the horse does not leadily respond even to large injections of filtrates carrying the active virus with the development of immunity principles within the blood. It is true that onl experiments are restrieted for the present to a single loolse, the blood serum of which, after many months of treatment, had no restraining effect on the virus either in vilro or within the body. 'The rabbit and ehicken would seem not to yield such immunity principles. On the other hand we Jave secured indications that the sheep may react more favorably. It has been found that normal sheep serum possesses a definite although slight neutralizing power for the filtered virus when mixed directly with it, and that the injection of emulsions of the spinal cord and brain of recently paralyzed monkeys into the sheep ausments this property of neutralization. What remains to be determined is the degree to which this augmentation can be carried, and whether a serm can be secured that will possess therapeutic value; but should the sheep fail in this respect, the senrch must be continued and be made to include still other species of animals, in the hope that one will be fornd in which the immunity response will he greater. 'Ihere are serions -objections to the use of monkeys as a source of a therapentic serum, even were one of high potency capahle of being prepared in those animals. 'The use of human serum, derived from persons who have passed through an attack of poliomyelitis, as a therapentic agent, would be f'ree of certain objections attached to the use of monkey serum, but it is not very probable that such an immune serum would be found to have sufficient strength or thent it could be procured with sufficient readiness to make it available for practical application. Finally, the serum treatment of poliomyelitis must at the present time be regarded as atrictly in the experimental state, and it can- 
not be predicted how soon or whether ever at all such a form of specific treatment of the disease will be applicable to the spontuneous epidemic disease in human beings.

\section{SUMMAMY}

It may be confidently stated that the experimental study of poliomyelitis has yielded a large number of important facts relating to the spontmeons disease in man. 'Tluese facts include the discovery of the nature of the virus, of many of its properties, of certain importunt clinical and pathological peculiaritios of the discase, of the phenomena of immunity of a morle of spontaneous infection, while they have served to establish a basis on which to develop measures of prevention, and on which to build hopes for the working out of a specific method of treatment. Moreover, the alvance which has now been acomplished will make it possible to determine with accuracy whether poliomyelitis is a single clinical and pathologic entity, or a generic name covering groups of symptoms and descriptive of the effects of certain lesions of the spinal covd and brain of which epidemic poliomyelitis is merely one, but the most important variety. It is not improbable that poliomyelitis, like meningitis, may be found to arise from several independent causes, and that epiclemic poliomyelitis, like epidemic meningitis, may be thistinguished among the varieties by being invariably the ploduct of a specific micro-organism. We possess alrearly evidence to the effect that certain of the lower amimals, among them poultry, the dog, and possibly the loorse, are subject to poliomyelitis, due apparently in each instance to a cause peculiar to the species affected.

\section{THE ARSENICAL TREATMEN'T OF SYPHILIS}

\section{JOHN J3. MURPHY, M.D.} CHICA(s)

Much attention has recently been paid to the arsenic treatment of syphilis and purticularly to the EhrlichHata preparation known as "(iofi", $i$. e., the dioxydianidoarsenobenzol diliydrochlorid. a single injection of: a proper dose of which is reporterl to be destructive of the Spirochota pallida. 'The recently recorded cases show a striking uniformity in the immediate curative effects in all of the spirilloses, or diseases of spirochetic origin.

It is believed that this arsenical preparation is as destructive of the spirochetes as quinin is of the plasmodia of malaria. The spirochetes disappear entirely from the local lesion and from the blood in from four to ten hours alter the injection of the remedy and the clisense appears to be entirely alrested in twenty-four hours. These seem astonishing statements but they are verified by a number of able observers as Ehrlich, Hata, Wechselmann, Alt of IChtspring, Schreiber of Magdeburg, Iversen of Russia and others.

The chemical composition of this drug as given by Dr. Bertheim, who mamufuctures it in the Royal Institute for Fxperimental Therapentics at Frankfurt under the directorship of Prof. Phirlich, is $\mathrm{C}_{12} \mathrm{H}_{12} \mathrm{O}_{2} \mathrm{~N}=\mathrm{As}$ and is expressed by fihrlich in the following formula:

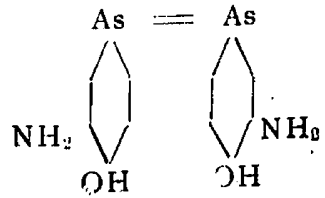

This arseno-benzol-dihydrochlorid preparation is a yellowish crystalline substance not mnlike iodoform in appearance and must be kept in lermetically sealed vials as the drug becomes very toxic when exposed to the air. For administration it must be handled with the greatest care and exact details in the technic must be carried ont.

The dose is a single injection of from 3 to 7 grains, given either intravenously or into the gluteal or pectoral muscles.

It is not yet available to the protession for general use. In a letter which I received a few days ago from Dr. C. H. Mekenna of Chicago, who was kind enough to go from Paris to Frankfurt at my request, he states that loe was received and treated by Prof. Ehrlich with the grentest courtesy and all the matters concerning this prejuation, the treatment and results, were placed at his disposal for observation. The details for the manu- lacture of the clrug are not given to the public; in this Prot. Fhrlich has exercised a praiscworthy caution. l'acing a drug that will be in such immediate demand all over the world, and used by men who do not exer. (.ise the preeaution of reading and following out in detail the directions given for its preparation and administration, is a hazardous procedure, and failure in securing the best results obtainable for the patients through this treatment would follow. The longest period that patients have been under observation after this treatment is abont eleven months. Prof. Ehrlich has reports on i,000 patients treated. In this number there were six deaths; Ehrlich himself considers that only one might justly be attributed to the treatment. This drug has been used in the treatment of syplitis in all stages from the primary chancres to the deep specific lesions of the contral nervous system. It seems to have the specific property of killing the spirochete in all its abodes in the tissue, $i$. $e$. of curing syphilis in its three stages-primary, secondary and tertiary. Its most prompt action is in: (1) the syphilids and mucous patches, (2) in the gummata and, (3) in the chancre; the latter, however, is sometimes very rapidly cured. The lymphatic adenopathies speedily disappear.

It does not and should not be expected to reproduce tissues that liave been destroyed by the spirochete. It will not restore destroyed columns of the cord or perforations of the palate or septum nor any other destroyed tissue. It does not produce an immediate increase in the size of the lesion by edema and swelling that was so marked in the enrly treatment of tuberculous lesions with tuberculin. Oin the contrary there is infiltration and therefore pressure on the neighboring structures. The drug relieves the shooting pain, the girdle sensation and the crises of tabes almost as a hypodermic of morphin would ; and it lessens the cephalalgia of the intracranial gummata.

One of the striking factors in favor of the claims of this treatment is that the most rapid effect is produced on the external or visible lesions. The cures appear to be permanent, as less than one-half dozen relapses have been recorded and most of these were easily truceable to deficient doses or to improper administration; but the patient promptly responded to a second injection. It will be noted that this is a far better result than is obtained in the average by quinin in ague or antitoxin in diphtheria and would liad us to hope that we have really another specific remedy. Regardless of what its permunent effect in definitely curing syphilis by a single dose 